\title{
Postplacental Placement of Intrauterine Devices: Acceptability, Reasons for Refusal and Proposals to Increase its Use
}

\section{Dispositivo intrauterino pós-placentário: Aceitação, motivos de recusas e propostas de ações que ampliem sua prática}

Maria Beatriz de Paula Leite Kraft ${ }^{1(} \quad$ Mariana Miadaira ${ }^{1(0)}$ Marcos Marangoni Júnior ${ }^{10}$ Cássia Raquel Teatin Juliato ${ }^{10}$ Fernanda Garanhani Surita ${ }^{10}$

${ }^{1}$ Department of Obstetrics and Gynecology, School of Medical Science, Universidade Estadual de Campinas, Campinas, SP, Brazil Rev Bras Ginecol Obstet 2021;43(3):172-177.
Address for correspondence Fernanda Garanhani Surita, MD, Associate Professor, R. Alexander Fleming, 101, 13083-881, Campinas, SP, Brazil (e-mail: surita@unicamp.br). received

February 13, 2020

accepted

January 6, 2021
Objective To evaluate the acceptability of postplacental placement of intrauterine devices (PPIUD), reasons for refusal and suggested policies to increase its use.

Methods Cross-sectional study conducted at the Women Hospital of the Universidade de Campinas, Campinas, SP, Brazil. Postplacental placement of intrauterine devices was offered to women admitted in labor who did not present infections, uterine malformation, twin pregnancy, preterm birth, and were at least 18 years old. In case of refusal, the parturient was asked to give their reasons and the answers were classified as misinformation about contraception or other reasons. The following were considered misinformation: fear of pain, bleeding, contraception failure and future infertility. Bivariate analysis was performed.

Results Amongst 241 invited women, the refusal rate was of $41.9 \%$. Misinformation corresponded to $50.5 \%$ of all refusals, and the reasons were: fear of pain (39.9\%); fear of contraception failure (4.9\%); fear of bleeding (3.9\%); fear of future infertility (1.9\%); other reasons for refusal were $49.5 \%$. Parturients aged between 18 and 27 years old refused the PPIUD more frequently due to misinformation (67.4\%), and older parturients (between 28 and 43 years old) refused frequently due to other reasons (63.6\%) $(p=0.002)$. The mean age of those who declined the PPIUD due to misinformation was $27.3 \pm 6.4$ years old, while those who declined for other reasons had a mean age of $29.9 \pm 5.9$ years old $(p=0.017)$.

Conclusion The refusal of the PPIUD was high, especially amongst young women and due to misinformation. It is necessary to develop educative measures during antenatal care to counsel women about contraception, reproductive health and consequences of unintended pregnancy.

- intrauterine device

health education

DOI https://doi.org/ $10.1055 / \mathrm{s}-0041-1725053$ ISSN $0100-7203$. (c) 2021. Federação Brasileira de Ginecologia e Obstetrícia. All rights reserved.

This is an open access article published by Thieme under the terms of the Creative Commons Attribution License, permitting unrestricted use, distribution, and reproduction so long as the original work is properly cited. (https://creativecommons.org/licenses/by/4.0/)

Thieme Revinter Publicações Ltda., Rua do Matoso 170, Rio de Janeiro, RJ, CEP 20270-135, Brazil 


\section{Resumo}

Palavras-chave
- pós-parto
- contracepção
- dispositivo
intrauterino
- educação em saúde

Objetivo Avaliar a taxa de aceitação do dispositivo intrauterino pós-placentário (DIUPP); os motivos de recusa e propor medidas que aumentem sua aceitação.

Métodos Estudo de corte transversal realizado no Hospital da Mulher da Universidade Estadual de Campinas, Campinas, SP, Brasil. O DIUPP foi oferecido a mulheres admitidas em trabalho de parto que não apresentavam: infecções, malformação uterina, gravidez gemelar, parto prematuro e com idade mínima de 18 anos. Em caso de recusa, perguntou-se o motivo, e as respostas foram agrupadas em informações equivocadas sobre contracepção ou outros motivos. Considerou-se informação equivocada: medo de dor, sangramentos, falha da contracepção e prejuízo da fertilidade. Análises bivariadas foram realizadas.

Resultados Entre 241 mulheres, a taxa de recusa foi de 41,9\%. A desinformação correspondeu a $50,5 \%$ de todos os motivos de recusa, que foram: medo da dor $(39,9 \%)$; medo da falha da contracepção (4,9\%); medo de sangramento (3,9\%), medo de o dispositivo intrauterino (DIU) prejudicar a fertilidade $(1,9 \%)$. Outros motivos de recusa atingem 49,5\%. Parturientes com idade entre 18 e 27 anos recusaram o PPIUD com mais frequência devido a desinformação $(67,4 \%)$, e as mais velhas (com idade entre 28 e 43 anos) recusaram com frequência devido a outros motivos $(63,6 \%)(p=0,002)$. Houve diferença entre a idade média de quem recusou o PPIUD por desinformação (27,3 $\pm 6,4$ anos) em comparação com outras razões ( $29,9 \pm 5,9$ anos), $(p=0,017)$. Além disso, ambos os grupos apresentaram altas taxas de recusa por desinformação, de 67,4 e $36,4 \%$, respectivamente.

Conclusão A recusa do DIUPP foi alta, principalmente entre as mulheres jovens e por desinformação. Diante disso, é necessário o desenvolvimento de medidas educativas durante o pré-natal e aconselhar as mulheres sobre contracepção, saúde reprodutiva e gravidez indesejada.

\section{Introduction}

Contraception is important to women as it allows them to decide whether it is the right time to conceive. In 2012, the occurrence rate of unintended pregnancies worldwide was of 53 for every 1,000 women aged between 15 and 44 years old, and its prevalence was of $40 \%{ }^{1}$ In the United States of America (USA), $50 \%$ of all pregnancies were unplanned ${ }^{2}$ and, in Brazil, the rate is $55.4 \% .^{3}$ Also, in some Brazilian regions, this figure rises to $65 \%$ (such as in the South). ${ }^{4}$ Amongst Brazilian women in the postpartum period, $25.5 \%$ reported feeling embarrassed to have conceived. ${ }^{3}$ These statistics reflect the importance of assuring contraception to all women. ${ }^{5}$ The postpartum period is a great opportunity to address contraceptive needs.

Nowadays, the most efficient contraceptive methods are long-acting reversible contraceptives (LARCs), including intrauterine devices (IUD) (copper and levonorgestrel [LNG] intrauterine systems) and subdermal progestin implants. They demand no changes in habit, are well tolerated, and are more effective than other methods with $<2$ pregnancies in 1,000 users. $^{6}$ Also, LARC methods have the lowest discontinuation rates. ${ }^{6}$ Still, short-term reversible methods are highly prescribed, ${ }^{7}$ even though studies show low continuation rates. ${ }^{8}$

Intrauterine devices must be offered to all women in reproductive age, especially after delivery, both vaginal and at the time of a cesarean delivery. In the USA, a study has shown that $35 \%$ of all pregnancies were accounted within 18 months after a previous pregnancy. Those pregnancies are more common among adolescent girls and are more likely to have been unplanned. ${ }^{9}$ The postpartum period is an opportunity to counsel women about contraception because, at that time, women often do not plan to conceive again in the near future. However, it is known that $~ 40 \%$ of women do not attend medical appointments in the postpartum period and that of all women after childbirth that are nursing, 20\% will ovulate again as early as in the 3rd month after parturition and, therefore, will be at risk of conceiving again. ${ }^{10}$

The period immediately after childbirth is a great opportunity to provide contraceptive methods, including LARCs. ${ }^{11-13}$ Therefore, it is important to evaluate the acceptability and refusal rates for these kinds of contraceptives, as well as the reasons for refusals, to create policies that stimulate women to adhere to contraception immediately after childbirth. The present study aims to evaluate the acceptance of PPIUD. Also, it is necessary to examine the refusal rate, the motives for refusal and the age of the patient at the time. These data are important to help in the creation of policies that could increase the acceptance of contraception immediately after childbirth. 


\section{Methods}

The present study was approved by the Ethical Committee of the Universidade de Campinas' (under number 80620717. 6.0000.5404) and is part of a large group of studies that analyze the insertion of IUDs immediately after childbirth.

The data presented in this cross-sectional study are from the recruitment of a large study, a clinical trial that compared expulsion of postplacental copper IUD and the LNG 52mg intrauterine system (IUS). ${ }^{14}$ Thus, the sample is intentional because it includes the necessary number of women invited to reach the sample size of the clinical trial.

The insertion of PPIUD was offered to women that would go through a cesarean delivery or were admitted in labor at the Women Hospital of the Universidade de Campinas. The exclusion criteria were the presence of any maternal infection or anemia, rupture of membranes for $>18$ hours, uterine malformation, or twin pregnancy. Also, the pregnancy had to have been $\geq 37$ weeks long and the parturient age had to be between 18 and 43 years old. If the parturient was classified as a candidate, PPIUD was offered. The present study was conducted between May 2018 and January 2019.

In case of acceptance, the patient was randomized to receive a TCu380A IUD or an LNG IUS, and a total of 70 units of each was inserted. In case of refusal, the woman was asked why she did not want PPIUD insertion. Subsequently, the refusal reasons were grouped according to misinformation or other reasons. Fear of pain, bleeding, contraception failure, and IUD impairing fertility were considered misinformation.

To evaluate if there was a statistical difference between the mean age of acceptance and refusal, the Mann-Whitney test was performed. Besides that, women who refused PPIUD were categorized in 2 age groups (between 18 and 27 years old versus between 28 and 43 years old) to analyze if the refusal motives showed any tendency (misinformation versus other reasons) among these groups ( $\mathrm{a} \mathrm{X}^{2}$ test was performed). Also, the mean age of the patients who refused PPIUD due to misinformation was compared with the mean age of the women who refused for other reasons, and a Mann-Whitney test was performed to evaluate if there was statistical significance. All information was analyzed by SAS Statistical Analysis System for Windows, version 9.2 (SAS Institute, Inc., Cary, NC, USA).

\section{Results}

Postplacental placement of intrauterine devices was offered to 241 women, of whom 140 accepted PPIUD insertion (58.1\%). Of all the patients involved, 74 were $<24$ years old (30.7\%), while 167 were between 25 and 43 years old (69.3\%). There was no significance in the mean age of the patients who refused or accepted PPIUD insertion ( - Table $\mathbf{1}$ ).

The motives to refuse the PPIUD are described in - Fig. 1. To correlate the refusal motives with the knowledge of the patient

Table 1 Postplacental intrauterine device placement acceptance and refusal according to women age

\begin{tabular}{llllll}
\hline \multicolumn{5}{l}{ Acceptance } & Refusal \\
\hline $\begin{array}{l}\text { Women age } \\
\text { (years old) }\end{array}$ & $n=140$ & $\%$ & $n=101$ & $\%$ & p-value \\
\hline $18-24$ & 46 & 32.9 & 28 & 27.7 & $0.825^{*}$ \\
$25-29$ & 41 & 29.3 & 31 & 30.7 & \\
$30-34$ & 30 & 21.4 & 22 & 21.8 & \\
$35-43$ & 23 & 16.4 & 20 & 19.8 & \\
Mean age/SD* & $27.9 \pm 5.8$ & $28.05 \pm 6.2$ & $0.506^{* *}$ \\
\hline
\end{tabular}

Abbreviation: SD, standard deviation.

${ }^{*}$ Chi-squared test

**Mann-Whitney test

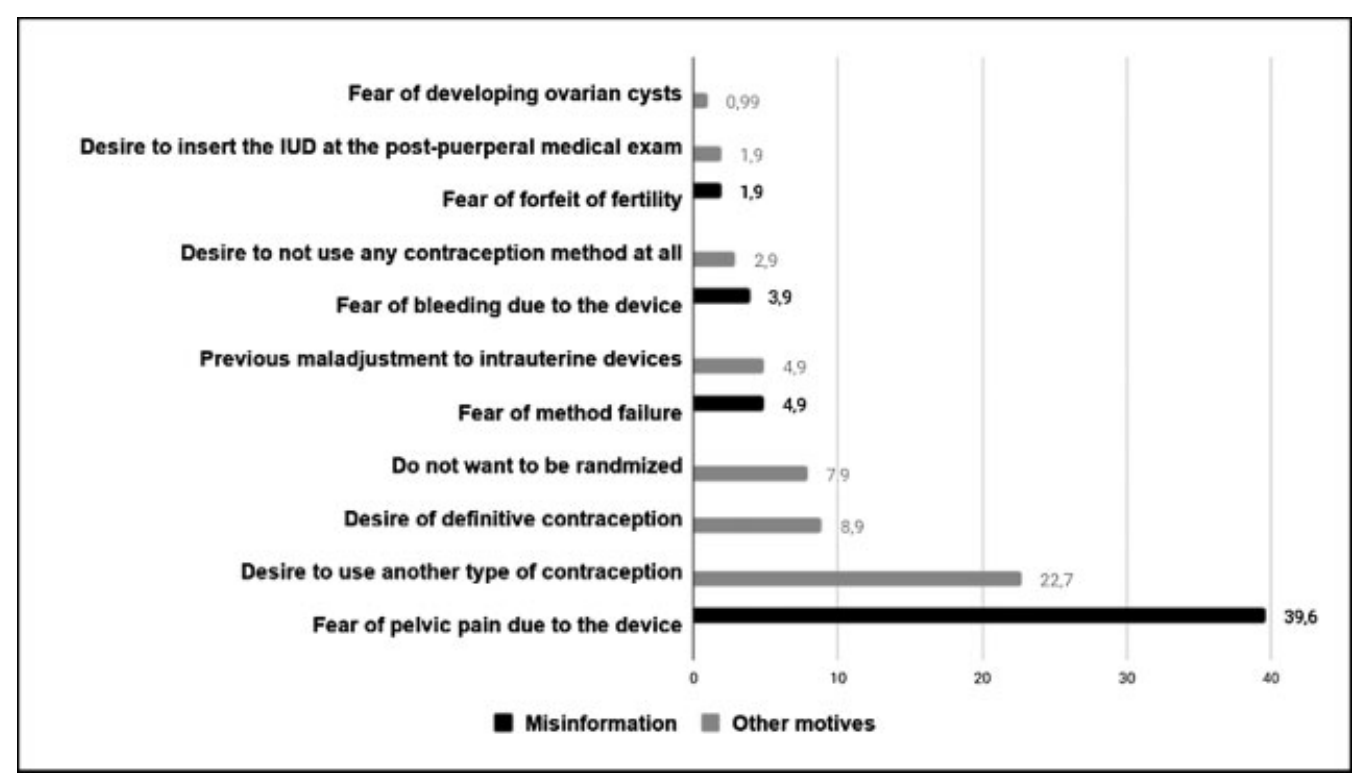

Fig. 1 Motives for refusal of postplacental intrauterine device placement 
Table 2 Refusal of post placental intrauterine device by misinformation and women age

\begin{tabular}{|c|c|c|c|c|c|}
\hline & \multicolumn{2}{|c|}{$\begin{array}{l}\text { Misinformation } \\
n=51(50.5 \%)\end{array}$} & \multicolumn{2}{|c|}{$\begin{array}{l}\text { Other reasons } \\
n=50(49.5 \%)\end{array}$} & \multirow[b]{2}{*}{ p-value } \\
\hline & Mean age & SD & Mean age & SD & \\
\hline & 27.3 & 6.4 & 29.9 & 5.4 & $0.017^{*}$ \\
\hline $\begin{array}{l}\text { Age groups } \\
\text { (years old) }\end{array}$ & $n$ & $\%$ & $n$ & $\%$ & \\
\hline $18-27$ & 31 & 60,78 & 15 & 30 & $0.002^{* *}$ \\
\hline $28-43$ & 20 & 39,21 & 35 & 70 & \\
\hline
\end{tabular}

*Mann-Whitney test

${ }^{* *}$ Chi-squared test

about contraception methods, fear of pain, bleeding, contraception failure and IUD impairing fertility (in black) were considered examples of misinformation. All other motives (in gray) were considered as not being correlated with misinformation (desire for nonreversible contraception methods such as sterilization or vasectomy; desire to use another type of contraception; desire to not use any contraception method at all; previous maladjustment to IUDs; fear of developing ovarian cysts; desire to insert the IUD at the postpuerperal medical consultation; and desire to not be randomized). Therefore, $50.5 \%$ of all refusals were due to a lack of knowledge of contraception methods, that is, misinformation.

It was also observed that patients aged between 18 and 27 years old were more likely to refuse PPIUD insertion due to misinformation $(67.4 \%)$ when compared with those aged between 28 and 43 years old (36.47\%), who usually refused this type of contraception because of other reasons (63.6\%), (chi-squared test; $p=0.002$ ). There was difference between the mean age of the patients who did not want the PPIUD insertion due to lack of knowledge ( $27.3 \pm 6$ years old) and of those who did not want it due to other reasons $(29.8 \pm 5.8$ years old), with statistical relevance (Mann-Whitney test; $p=0.017$ ). In all ages, the refusal rate due to misinformation was high (67.4 and $36.47 \%$, respectively). These data are summarized in - Table 2.

\section{Discussion}

Our study showed that the rate of refusal of IUDs immediately after childbirth was high (41.9\%), mainly due to lack of information about IUD by the patients, especially amongst younger women.

The practice of PPIUD insertion has gained attention recently and is recommended by the World Health Organization (WHO). It should be considered an excellent contraceptive method, because women are rarely in such frequent and intense contact with health professionals as they are during pregnancy and the immediate postpartum period. Therefore, this period is a good opportunity to promote education and provide counseling in reproductive health.

After childbirth, it is common for recent mothers to develop many concerns about the newborn and often forget about their own health. The fact that $40 \%$ of all women who give birth do not attend puerperal appointments ${ }^{9}$ reflects this loss of self- care. Also, it is common for women after childbirth to think less about contraception, ${ }^{15}$ and any period with no protection could result in an unintended pregnancy. ${ }^{16}$ Since the antenatal visits will be the period when a woman has most frequent contact with a healthcare provider, it is also the duty of the healthcare provider to discuss the reproductive future of the woman. The period immediately after childbirth is a good opportunity to initiate contraception, including IUDs, because the patient is not pregnant, probably does not want to conceive in the near future, and will not feel pain during its insertion. It is important to study the acceptance rates of the use of contraception immediately after childbirth, as well as the motives for its refusal, in order to promote this type of family planning.

The present study showed that slightly more than half of the patients accepted PPIUD, and their mean age was 28 years old. The refusal rate was high (41.9\%), and the most frequent refusal motives were misinformation about IUD, such as: fear of pain, bleeding, contraception failure and IUD impairing fertility. Intrauterine devices do not cause pelvic pain, prejudice fertility, or have a high failure risk. ${ }^{6,17,18}$ As for bleeding, although copper IUDs may increase menstrual blood flow, this can be easily controlled with medication. These refusal motives can, therefore, be easily demystified, but only by properly counseling the patients about this method. Patients aged between 18 and 27 years old and between 28 and 43 years old refused PPIUD insertion frequently due to lack of information and, amongst the younger patients, the chances of refusing this contraception due to misinformation are higher.

The present study has some limitations. The sample size is intentional, based on the sample calculated for a randomized study. ${ }^{14}$ Epidemiological data, such as race and education, were not collected. However, we consider the results obtained in this simple analysis very strong. Recognizing misinformation as a barrier to PPIUD use, especially amongst those of a young age, is the first step in the development of public policies on contraception that should be added to others such as training of healthcare professionals. Other studies performed in developing countries have also shown that the lack of IUD awareness impacts on low acceptance of this type of contraception and encourage policies to educate women about contraception and IUDs. ${ }^{19}$ These studies agree that educating couples about contraception and antenatal care increases PPIUD usage. ${ }^{20}$ 
As other studies, the present study shows that misinformation about contraception is frequent amongst women, and that this failure facilitates the occurrence of unintended pregnancies. $^{21,22}$ Also, basic interventions such as counseling increase IUD acceptance, ${ }^{23}$ and multiple approaches on this matter enhance the rate of acceptance by women immediately after parturition. ${ }^{24} \mathrm{~A}$ recent study showed that with PPIUD, almost all the expulsions occurred within 42 days after childbirth, and suggests special attention during this period to identify premature expulsions. ${ }^{14}$ Postplacental placement of IUD or intrauterine system (IUS) is associated with less discomfort during the procedure; however, it is associated with higher expulsion rates than other interval placements. ${ }^{25}$

The period of gestation is, therefore, an excellent moment to clarify with women the importance of contraceptive methods, the preference for long-term methods, the benefits of IUD, and the advantages of its insertion immediately after childbirth. Obstetricians and gynecologists and other health care agents should frequently talk to pregnant women about family planning. Other important information that should be shared with pregnant women is that contraception immediately after delivery improves perinatal outcomes for the woman herself and for the newborn - studies show an increase in child survival rates, a decrease in unintended pregnancies and maternal mortality, and a reduction in maternal depression. ${ }^{26-28}$

\section{Conclusion}

The present study has showed that the rate of refusal of IUDs after childbirth was high, mainly due to lack of information about the devices by the patients, especially amongst younger women. Policies need to be revised to increase contraception awareness after childbirth, through measures such as family planning groups with pregnant women, information sheets and counseling during prenatal care appointments.

\section{Contributions}

Surita F. G. and Juliato C. R. T. designed the research; data collection was performed by Kraft M. B. P. L.. Miadaira M., Marangoni M. Jr.,Kraft M. B. P. L. and Surita F. G. performed the statistical analysis. Kraft M. B. P. L.wrote the paper; all authors revised this version. Kraft M. B. P. L. and Surita F. G. had primary responsibility for the final content.

\section{Conflict of Interests}

The authors have no conflict of interests to declare.

\section{References}

1 Sedgh G, Singh S, Hussain R. Intended and unintended pregnancies worldwide in 2012 and recent trends. Stud Fam Plann. 2014; 45(03):301-314. Doi: 10.1111/j.1728-4465.2014.00393.x

2 Henshaw SK. Unintended pregnancy in the United States. Fam Plann Perspect. 1998;30(01):24-29, 46

3 Theme-Filha MM, Baldisserotto ML, Fraga ACSA, Ayers S, da Gama $S G$, Leal MD. Factors associated with unintended pregnancy in Brazil: cross-sectional results from the Birth in Brazil National
Survey, 2011/2012. Reprod Health. 2016;13(Suppl 3):118. Doi: 10.1186/s12978-016-0227-8

4 Prietsch SOM, González-Chica DA, Cesar JA, Mendoza-Sassi RA. Gravidez não planejada no extremo Sul do Brasil: prevalência e fatores associados. Cad Saude Publica. 2011;27(10):1906-1916. Doi: $10.1590 /$ S0102-311 × 2011001000004

5 Ministério da Saúde Pesquisa Nacional de Demografia e Saúde da Criança e da Mulher - PNDS 2006: dimensões do processo reprodutivo e da saúde da criança Brasília (DF): Ministério da Saúde;. 2009

6 Trussell J. Contraceptive efficacy. In: Hatcher RA, Trussel J, Nelson AL, Cates W, Stewart RH, Kowal D, et al., eds. Contraceptive technology. 20th ed. New York: Ardent Media; 2011:779-863

7 Mosher WD, Jones JNational Center for Health Statistics. Use of contraception in the United States: 1982-2008. Vital Health Stat 23. 2010;(29):1-44

8 Hall KS, Castaño PM, Westhoff CL. The influence of oral contraceptive knowledge on oral contraceptive continuation among young women. J Womens Health (Larchmt). 2014;23(07):596-601. Doi: 10.1089/jwh.2013.4574

9 Gemmill A, Lindberg LD. Short interpregnancy intervals in the United States. Obstet Gynecol. 2013;122(01):64-71. Doi: 10.1097/ AOG.0b013e3182955e58

10 Ogburn JA, Espey E, Stonehocker J. Barriers to intrauterine device insertion in postpartum women. Contraception. 2005;72(06): 426-429. Doi: 10.1016/j.contraception.2005.05.016

11 Celen S, Möröy P, Sucak A, Aktulay A, Danişman N. Clinical outcomes of early postplacental insertion of intrauterine contraceptive devices. Contraception. 2004;69(04):279-282. Doi: 10.1016/j.contraception.2003.12.004

12 Tocce KM, Sheeder JL, Teal SB. Rapid repeat pregnancy in adolescents: do immediate postpartum contraceptive implants make a difference? Am J Obstet Gynecol. 2012;206(06):481.e1-481.e7. Doi: 10.1016/j.ajog.2012.04.015

13 Washington CI, Jamshidi R, Thung SF, Nayeri UA, Caughey AB, Werner EF. Timing of postpartum intrauterine device placement: a cost-effectiveness analysis. Fertil Steril. 2015;103(01):131-137. Doi: $10.1016 /$ j.fertnstert.2014.09.032

14 Laporte M, Marangoni M Jr, Surita F, Juliato CT, Miadaira M, Bahamondes L. Postplacental placement of intrauterine devices: A randomized clinical trial. Contraception. 2020;101(03): 153-158. Doi: 10.1016/j.contraception.2019.12.006

15 Teal SB. Postpartum contraception: optimizing interpregnancy intervals. Contraception. 2014;89(06):487-488. Doi: 10.1016/j. contraception.2014.04.013

16 Allen RH, Goldberg AB, Grimes DA. Expanding access to intrauterine contraception. Am J Obstet Gynecol. 2009;201(05):456. e1-456.e5. Doi: 10.1016/j.ajog.2009.04.027

17 Anpalagan A, Condous G. Is there a role for use of levonorgestrel intrauterine system in women with chronic pelvic pain? J Minim Invasive Gynecol. 2008;15(06):663-666. Doi: 10.1016/j.jmig.2008.07.008

18 Andersson K, Batar I, Rybo G. Return to fertility after removal of a levonorgestrel-releasing intrauterine device and Nova-T. Contraception. 1992;46(06):575-584. Doi: 10.1016/0010-7824(92)90122-a

19 Ezugwu EC, Achara JI, Ezugwu OC, Ezegwui HU. Acceptance of postpartum intrauterine contraceptive device among women attending antenatal care in a low-resource setting in Nigeria. Int J Gynaecol Obstet. 2020;148(02):181-186. Doi: 10.1002/ ijgo. 13027

20 Da Costa V, Ingabire R, Sinabamenye R, Karita E, Umutoni V, Hoagland $A$, et al. An exploratory analysis of factors associated with interest in postpartum intrauterine device uptake among pregnant women and couples in Kigali, Rwanda. Clin Med Insights Reprod Health. 2019; 13:1179558119886843. Doi: 10.1177/1179558119886843

21 Rosenberg MJ, Waugh MS, Long S. Unintended pregnancies and use, misuse and discontinuation of oral contraceptives. J Reprod Med. 1995;40(05):355-360 
22 Castaño PM, Bynum JY, Andrés R, Lara M, Westhoff C. Effect of daily text messages on oral contraceptive continuation: a randomized controlled trial. Obstet Gynecol. 2012;119(01):14-20. Doi: 10.1097/AOG.0b013e31823d4167

23 Arrowsmith ME, Aicken CRH, Saxena S, Majeed A. Strategies for improving the acceptability and acceptance of the copper intrauterine device. Cochrane Database Syst Rev. 2012;(03): CD008896. Doi: 10.1002/14651858.CD008896.pub2

24 Makins A, Taghinejadi N, Sethi M, et al. Factors influencing the likelihood of acceptance of postpartum intrauterine devices across four countries: India, Nepal, Sri Lanka, and Tanzania. Int J Gynaecol Obstet. 2018;143(Suppl 1):13-19. Doi: 10.1002/ijgo.12599

25 Jatlaoui TC, Whiteman MK, Jeng G, Tepper NK, Berry-Bibee E, Jamieson DJ, et al. Intrauterine device expulsion after postpartum placement: a systematic review and meta-analysis. Obstet Gynecol. 2018;132(04):895-905. Doi: 10.1097/AOG.0000000000002822

26 Kozuki N, Lee AC, Silveira MF, Victora CG, Adair L, Humphrey J, et al; Child Health Epidemiology Reference Group Small-forGestational-Age-Preterm Birth Working Group. The associations of birth intervals with small-for-gestational-age, preterm, and neonatal and infant mortality: a meta-analysis. BMC Public Health. 2013;13(Suppl 3):S3. Doi: 10.1186/1471-2458-13-S3-S3

27 Cleland J, Conde-Agudelo A, Peterson H, Ross J, Tsui A. Contraception and health. Lancet. 2012;380(9837):149-156. Doi: 10.1016/ S0140-6736(12)60609-6

28 Brito CNO, Alves SV, Ludermir AB, Araújo TVB. Depressão pósparto entre mulheres com gravidez não pretendida. Rev Saude Publica. 2015;49:33. Doi: 10.1590/S0034-8910.2015049005257 